Journal of Computer Science 7 (6): 854-858, 2011

ISSN 1549-3636

(C) 2011 Science Publications

\title{
Nonlinear Control Design of Shunt Flexible AC Transmission System Devices for Damping Power System Oscillation
}

\author{
Prechanon Kumkratug \\ Department of Electrical Engineering, Faculty of Engineering at Si Racha, \\ Kasetsart University, 199 M.6, Tungsukhla, Si Racha, Chonburi, 20230, Thailand
}

\begin{abstract}
Problem statement: The disturbance in the complicated network of power system may cause in nonlinear response. Static Synchronous Compensator (STATCOM) is a power electronic based device that has the capability of controlling the line current. This study applies the STATCOM to decrease the over line current in power system during dynamic state. Approach: This study proposes the control strategy of a STATCOM to enlarge the stability region of a simple power system. The control is determined very carefully to satisfy the Lyapunov's stability criterion and is found to be a non-linear function of system states. The proposed nonlinear control of STATCOM for damping power system oscillation is investigated through the sample system. Results: The maximum generator rotor angle of the faulted system without a STATCOM is continuously oscillation and the maximum value is much more than the system with a STATCOM. Conclusion: STATCOM based the proposed nonlinear control can damp power system oscillation.
\end{abstract}

Key words: Power system stability, power system oscillation, FACTS devices, Static Synchronous Series Compensator (SSSC), Single Machine Infinite Bus (SMIB), voltage injection, voltage source, short circuit

\section{INTRODUCTION}

Modern power system network is getting much more complicated and heavily loaded than ever before. The consequences of such are the difficulty of power flow and risk of stability problem. Flexible AC Transmission System (FACTS) devices have been proposed to improve stability of power system (Barbuy et al., 2009; Hassan et al., 2010a; Fernandes et al., 2009; Omar et al., 2010; Osuwa and Igwiro, 2010; Santos et al., 2010). They have proposed many methods to improve stability of power system such as load shedding, High Voltage Direct Current (HVDC), Flexible AC Transmission system (FACTS), (AlHusban, 2009; Hassan et al., 2010b ; Kumkratug, 2010; Meshkatoddini et al., 2009; Hannan et al., 2009; Zarate-Minano et al., 2010).

A Static Synchronous Compensator (STATCOM) is a member of the FACTS family that is connected in shunt with power system. The STATCOM consists of a solid state voltage source converter with GTO thyristor switches or other high performance of semi-conductor and transformer. The STATCOM can electrically mimic reactor and capacitor by injecting a shunt current in quadrature with the line voltage. The reactive power (or current) of the STATCOM can be adjusted by controlling the magnitude and phase angle of the output voltage of the shunt converter (Al-Husban, 2009; Mustafa and Magaji, 2009).
The disturbance in the complicated network of power system may cause in nonlinear response. This study presents the nonlinear control of STATCOM for damping power oscillation. The proposed control is based on Lyapunov's theory. The simulation results are tested on a sample system. The effect of STATCOM on damping power system oscillation is investigated in various cases.

\section{MATERIALS AND METHODS}

Mathematical model: Fig. 1a shows the single line diagram of the Single Machine Infinite Bus (SMIB) system with a STATCOM at bus $m$. First consider the system without the STATCOM and the corresponding equivalent circuit is shown in Fig. 1b. Here $\mathrm{X}_{1}$ is the equivalent reactance between the machine internal bus and the bus $m$ and $X_{2}$ is the equivalent reactance between bus $\mathrm{m}$ and the infinite bus. The generator is representing by a constant voltage source (E') behind transient reactance. The equivalent circuit of the system with a STATCOM is shown in Fig. 1c where the STATCOM is represented by a shunt current. Note that the injected current of the STATCOM is always in quadrature with its terminal voltage. 


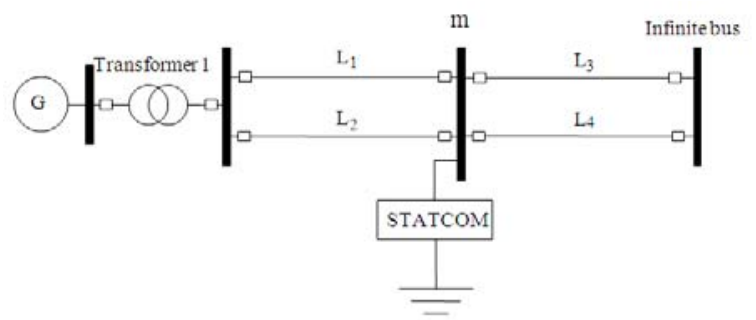

(a)

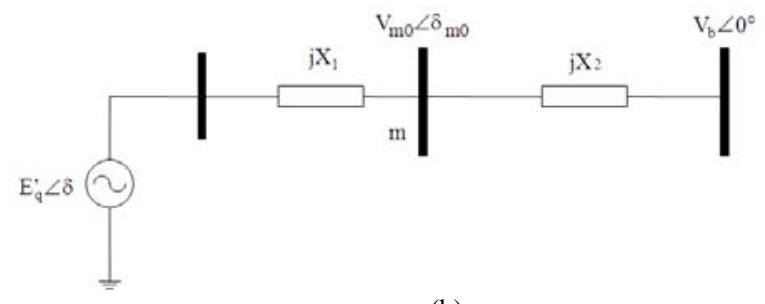

(b)

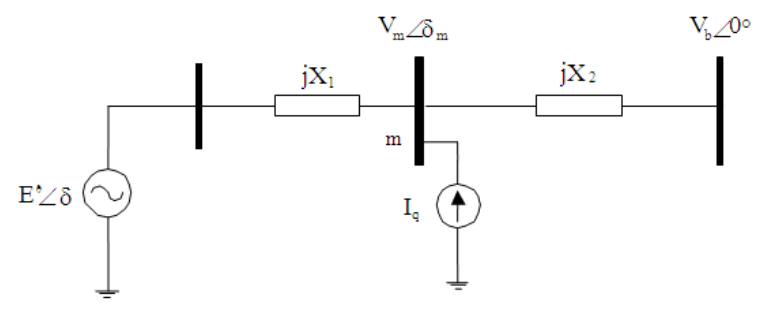

(c)

Fig. 1: A Single Machine Infinite Bus (SMIB) system with STATCOM; (a) A single line diagram; (b) Equivalent circuit of SMIB system without STATCOM; (c) Equivalent circuit of SMIB system with a STATCOM represented by a current injection model

The dynamics of the generator, without the STATCOM, can be expressed by the following differential equations 1 and 2 :

$\dot{\delta}=\omega$

$\dot{\omega}=\frac{1}{\mathrm{M}}\left[\mathrm{P}_{\mathrm{m}}-\mathrm{P}_{\mathrm{e} 0}\right]$

Here $\delta, \omega \mathrm{M}$ and $\mathrm{P}_{\mathrm{m}}$, are the rotor angle, speed, input mechanical power, moment of inertia and output mechanical power, respectively, of the generator. $\mathrm{P}_{\mathrm{e} 0}$ is output electrical power of generator without the STATCOM and is given by Eq. 3-7:

$\mathrm{P}_{\mathrm{eo}}=\frac{\mathrm{E}^{\prime} \mathrm{V}_{\mathrm{mo}}}{\mathrm{X}_{1}} \sin \left(\delta-\delta_{\mathrm{mo}}\right)$
Here, $\mathrm{V}_{\mathrm{mo}}$ and $\delta_{\mathrm{m} 0}$ represent the voltage magnitude and angle at bus $\mathrm{m}$ without the STATCOM and are given by:

$$
\begin{aligned}
& \delta_{\mathrm{m} 0}=\tan ^{-1}\left[\frac{\mathrm{X}_{2} \mathrm{E}^{\prime} \sin \delta}{\mathrm{X}_{2} \mathrm{E}_{\mathrm{q}}^{\prime} \cos \delta+\mathrm{X}_{1} \mathrm{~V}_{\mathrm{b}}}\right] \\
& \mathrm{V}_{\mathrm{m} 0}=\left(\frac{\mathrm{X}_{2} \mathrm{E}^{\prime} \cos \left(\delta-\delta_{\mathrm{m}}\right)+\mathrm{X}_{1} \mathrm{~V}_{\mathrm{b}} \cos \delta_{\mathrm{m}}}{\mathrm{X}_{1}+\mathrm{X}_{2}}\right)
\end{aligned}
$$

In general form, equations (1) and (2) can be written as:

$$
\dot{\mathrm{x}}=\mathrm{f}_{0}(\mathrm{x})
$$

Where:

$$
\mathrm{x}=\left|\begin{array}{l}
\mathrm{x}_{1} \\
\mathrm{x}_{2}
\end{array}\right|=\left|\begin{array}{l}
\delta \\
\omega
\end{array}\right|
$$

And:

$$
f_{0}(x)=\left|\begin{array}{c}
f_{01}(x) \\
f_{02}(x)
\end{array}\right|=\left|\begin{array}{c}
\omega \\
\frac{P_{m}-P_{e 0}}{M}
\end{array}\right|
$$

Now, consider the system with the STATCOM at bus $m$ as shown Fig. 1c. The injected current of the STATCOM for capacitive mode of operation can be expressed as:

$$
\mathbf{I}_{\mathrm{q}}=\mathrm{I}_{\mathrm{q}} \angle \delta_{\mathrm{m}}-90^{\circ}
$$

With the STATCOM, the voltage magnitude and angle at bus $m$ can be written as Eq. 8 and 9:

$$
\begin{aligned}
\delta_{\mathrm{m}}= & \tan ^{-1}\left[\frac{\mathrm{X}_{2} \mathrm{E}^{\prime} \sin \delta}{\mathrm{X}_{2} \mathrm{E}_{\mathrm{q}}^{\prime} \cos \delta+\mathrm{X}_{1} \mathrm{~V}_{\mathrm{b}}}\right] \\
\mathrm{V}_{\mathrm{m}} & =\left(\frac{\mathrm{X}_{2} \mathrm{E}^{\prime} \cos \left(\delta-\delta_{\mathrm{m}}\right)+\mathrm{X}_{1} \mathrm{~V}_{\mathrm{b}} \cos \delta_{\mathrm{m}}}{\mathrm{X}_{1}+\mathrm{X}_{2}}\right) \\
& +\left(\frac{\mathrm{X}_{1} \mathrm{X}_{2}}{\mathrm{X}_{1}+\mathrm{X}_{2}} \mathrm{I}_{\mathrm{q}}\right)
\end{aligned}
$$

Note that $\delta_{\mathrm{m}}$ of (8) is exactly the same as $\delta_{\mathrm{m} 0}$ of (4). That is the STATCOM current does not change the angle of the voltage at bus $\mathrm{m}$. However, the voltage magnitude of bus m depends on the STATCOM current 
$I_{q}$ as can be seen in (9). Note that the first term on the right hand side of (9) is the same as $V_{m 0}$ of (5) and the second term represent the contribution of the STATCOM current. Thus $\mathrm{V}_{\mathrm{m}}$ can be expressed as:

$\mathrm{V}_{\mathrm{m}}=\mathrm{V}_{\mathrm{m} 0}+\mathrm{C}_{1} \mathrm{I}_{\mathrm{q}}$

Where:

$$
\mathrm{C}_{1}=\frac{\mathrm{X}_{1} \mathrm{X}_{2}}{\mathrm{X}_{1}+\mathrm{X}_{2}}
$$

Using Fig. 1c, the output electrical power $\mathrm{P}_{\mathrm{e}}$ of generator, with the STATCOM, can be written as:

$$
P_{e}=\frac{E^{\prime} V_{m}}{X_{1}} \sin \left(\delta-\delta_{m}\right)
$$

Using (10) and (11), $\mathrm{P}_{\mathrm{e}}$ can be expressed as:

$\mathrm{P}_{\mathrm{e}}=\mathrm{P}_{\mathrm{e} 0}+\mathrm{C}_{2} \mathrm{I}_{\mathrm{q}} \sin \left(\delta-\delta_{\mathrm{m}}\right)$

Where:

$$
C_{2}=\frac{E^{\prime} C_{1}}{X_{1}}
$$

It may be mentioned here that the above equations are derived for capacitive mode of operation of the STATCOM. For inductive mode of operation, $I_{q}$ in (9), (10) and (12) needs to be replaced by $-\mathrm{I}_{\mathrm{q}}$. Thus the dynamic equations of the generator with the STATCOM becomes Eq. 13:

$\dot{\mathrm{x}}=\mathrm{f}(\mathrm{x}, \mathrm{u})=\mathrm{f}_{0}(\mathrm{x})+\mathrm{uf}_{1}(\mathrm{x})$

Where:

And:

$$
\mathrm{u}=\mathrm{I}_{\mathrm{q}}
$$

$$
f_{1}(x)=\left[\begin{array}{c}
f_{11}(x) \\
f_{12}(x)
\end{array}\right]=\left[\begin{array}{c}
0 \\
\frac{-C_{2} \sin \left(\delta-\delta_{m}\right)}{M}
\end{array}\right]
$$

The system states $\mathrm{x}$ and function $\mathrm{f}_{0}$ are already defined in (6). It may be mentioned here that the damping of a system can be improved by controlling the output electrical power of generator which depends on both angle $\delta$ and STATCOM current $\mathrm{I}_{\mathrm{q}}$.
Control strategy: Liapuvov's second or direct method is a very powerful tool of assessing the stability of a non-linear system. In this study, the concept of the Lyapunov's stability criterion is used to select control strategy of the STATCOM. A positive definite Lyapunov function V of the simple SMIB system can be considered as (Zarate-Minano et al., 2010) Eq. 14:

$$
\mathrm{V}(\delta, \omega)=\frac{1}{2} \mathrm{M} \omega^{2}-\mathrm{P}_{\mathrm{m}} \delta-\left(\mathrm{E}^{\prime} \mathrm{V}_{\mathrm{b}} / \mathrm{X}_{1}\right) \cos \delta+\mathrm{C}_{0}
$$

The basis of the Lyapunov's stability theory is that the time derivative of $\mathrm{V}(\mathrm{x})$ must be negative semidefinite along the post fault trajectory. The time derivative of $\mathrm{V}(\mathrm{x})$ can be written as:

$$
\begin{aligned}
\dot{V}(x) & =\frac{\partial V}{\partial x} \frac{d x}{d t}=\frac{\partial V(x)}{\partial x}\left[f_{0}(x)+f_{1}(x)\right] \\
= & \frac{\partial V(x)}{\partial x} f_{0}(x)+\frac{\partial V(x)}{\partial x} u_{1}(x)
\end{aligned}
$$

Thus the Lyapunov's stability criterion can be satisfied by making both terms on the right hand side of (15) as negative semi-definite. The first term on the right hand side of (15) represents $\dot{V}$ without the STATCOM and is given by Eq. 16:

$$
\begin{aligned}
& \dot{\mathrm{V}}_{0}(\mathrm{x})=\frac{\partial \mathrm{V}(\mathrm{x})}{\partial \mathrm{x}} \mathrm{f}_{0}(\mathrm{x}) \\
& {\left[\begin{array}{ll}
-\mathrm{P}_{\mathrm{m}}+\mathrm{P}_{\mathrm{e} 0} & \mathrm{M} \omega
\end{array}\right]\left[\frac{\mathrm{P}_{\mathrm{m}} \omega-\mathrm{P}_{\mathrm{e}}}{\mathrm{M}}\right]=0}
\end{aligned}
$$

The second term on the right hand side of (15) represents the contribution of the STATCOM to $\dot{\mathrm{V}}$ and is given by:

$$
\begin{aligned}
& \dot{\mathrm{V}}_{1}(\mathrm{x})=\frac{\partial \mathrm{V}(\mathrm{x})}{\partial \mathrm{x}} \mathrm{uf}_{1}(\mathrm{x}) \\
& =\left[\begin{array}{ll}
-\mathrm{P}_{\mathrm{m}}+\mathrm{P}_{\mathrm{e} 0} \quad \mathrm{M} \omega
\end{array}\right] \mathrm{u}\left[\begin{array}{c}
0 \\
\frac{-\mathrm{C}_{2} \sin \left(\delta-\delta_{\mathrm{m}}\right)}{\mathrm{M}}
\end{array}\right] \\
& =-\mathrm{uC}_{2} \omega \sin \left(\delta-\delta_{\mathrm{m}}\right)
\end{aligned}
$$

One of the possible candidates of $u$ that guarantees the negative semi-definiteness criterion of (17) can be considered as:

$\mathrm{u}=\mathrm{K} \omega \sin \left(\delta-\delta_{\mathrm{m}}\right)$ 
Here, $\mathrm{K}$ is a positive constant. Note that for positive values of $X_{1}$ and $X_{2}$, the angle $\delta_{m}$ in Fig. 1c always lies in between zero and $\delta$. When $-\pi \leq \delta \leq \pi$, the sign of $\sin (\delta$ $\delta_{\mathrm{m}}$ ) becomes the same as the sign of $\sin \delta$. Thus without changing the sign criterion of $\dot{\mathrm{V}}$, the control $\mathrm{u}$ of (18) can also be considered as:

$\mathrm{u}=\mathrm{K} \omega \sin \delta$

It can be seen in (19) that the proposed control is a non-linear function of generator angle and speed. When the STATCOM is not placed near the generator, these signals need to be estimated from some local information.

\section{RESULTS}

The proposed nonlinear control of STATCOM for damping power system oscillation will be investigated through the sample system. Figure 2 shows the sample system. The system parameters are:

$\mathrm{M}=5.6, \mathrm{X}_{\mathrm{t}}=0.1, \mathrm{X}_{\mathrm{d}}{ }_{\mathrm{d}}=3, \mathrm{X}_{\mathrm{L} 1}=0.4, \mathrm{X}_{\mathrm{L} 2}=0.4, \mathrm{X}_{\mathrm{L} 3}=0.9$, $\mathrm{X}_{\mathrm{L} 4}=0.4, \mathrm{P}_{\mathrm{m}}=0.9$

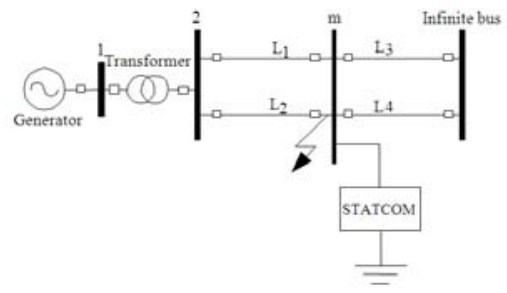

Fig. 2: Sample system

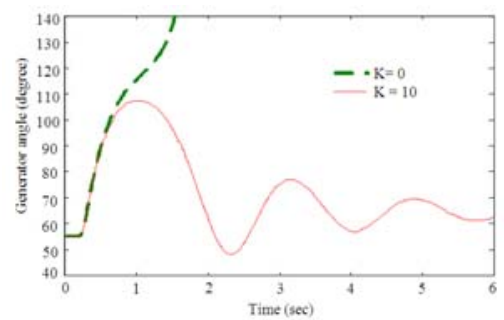

Fig. 3: The generator rotor angle of the system with and without a STATCOM

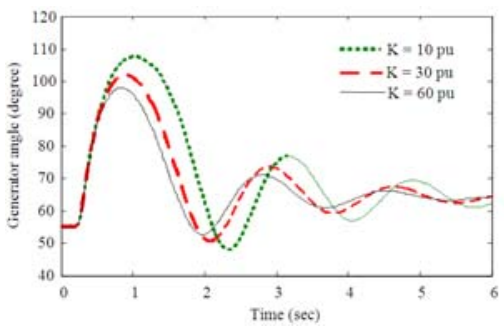

Fig. 4: The generator rotor angle of the system with various gains of STATCOM
It is considered that a 3-phase fault appears on line L1 and it is cleared by opening the faulted line. Figure 3 shows the generator rotor angle curve of the system with and without a STATCOM. Figure 4 shows the generator rotor angle curve of the system with various gains of a STATCOM.

\section{DISCUSSION}

It can be observed from the simulation results that the system without a STATCOM $(\mathrm{K}=0)$ the generator rotor angle increases monotonously and it is considered as unstable whereas the system with a STATCOM $(\mathrm{K}=10)$ can be considered as stable. This study also investigates the effect of increasing the gain on damping improvement. With the $\mathrm{K}=10$, the maximum generator rotor angle is around $107^{\circ}$. With $\mathrm{K}=120$, the maximum is decreased to $97^{\circ}$.

\section{CONCLUSION}

Static Synchronous Compensator (STATCOM) is shunt FACTS devices. It has capability of improving power system oscillation. This study presents the nonlinear control of STATCOM for damping power system oscillation. The proposed control strategy is derived from Lyapunov's theory. The proposed nonlinear control of a STATCOM is tested on sample system. It was found that the STATCOM can damp power system oscillation. The maximum of the generator rotor angle can be decreased by increasing the gain.

\section{REFERENCES}

Al-Husban, A.N., 2009. An eigenstructure assignment for a static synchronous compensator. Am. J. Eng. Applied Sci., 2: 812-816. $\quad$ DOI: 10.3844/ajeassp.2009.812.816

Barbuy, H.S., A. Rocco, L.A.P. Fernandes and G.C. Guimaraes, 2009. Voltage collapse risk associated to under-voltage capacitive compensation in electric power system operation. Am. J. Applied Sci., 6: 646-651. DOI: 10.3844/ajassp.2009.646.651

Fernandes, L.A.P., A. Rocco, H.S. Barbuy and G.C. Guimaraes, 2009. Electric power system under-voltage load shedding protection can become a trap. Am. J. Applied Sci., 6: 1526-1530. DOI: 10.3844/ajassp.2009.1526.1530

Hannan, M.A., A. Mohamed, A. Hussian and M. Dabbay, 2009. Development of the unified seriesshunt compensator for power quality mitigation. Am. J. Applied Sci., 6: 978-986. DOI: 10.3844/ajassp.2009.978.986 
Hassan, L.H., M. Moghavvemi and H.A.F. Mohamed, 2010b. Power system oscillations damping using unified power flow controller-based stabilizer. Am. J. Applied Sci., 7: 1393-1395. DOI: 10.3844/ajassp.2010.1393.1395

Hassan, L.H., M. Moghavvemi and H.A.F. Mohamed, 2010a. Takagi-Sugeno fuzzy gains scheduled pi controller for enhancement of power system stability. Am. J. Applied Sci., 7: 145-152. DOI: 10.3844/ajassp.2010.145.152

Kumkratug, P., 2010. Improvement of transient stability of power system by thyristor controlled phase shifter transformer. Am. J. Applied Sci., 7: 1495-1499. DOI: 10.3844/ajassp.2010.1495.1499

Meshkatoddini, M.R., M. Majidi, M. Sadeghierad and H. Lesani, 2009. Comparison of UPFC-based stabilizer and PSS performances on damping of power system oscillations. Am. J. Applied Sci., 6: 401-406. DOI: 10.3844/ajassp.2009.401.406

Mustafa, M.W. and N. Magaji, 2009. Optimal location of static var compensator device for damping oscillations. Am. J. Engineer. Applied Sci., 2: 353-359. DOI: 10.3844/ajeassp.2009.353.359
Omar, R., N.A. Rahim and M. Sulaiman, 2010. New control technique applied in dynamic voltage restorer for voltage sag mitigation. Am. J. Applied Sci., 3: 42-48. DOI: 10.3844/ajeassp.2010.42.48

Osuwa, J.C. and E.C. Igwiro, 2010. Uninterruptible power supply using solar rechargeable battery. Phy. Int., 1: 77-82. DOI: 10.3844/pisp.2010.77.82

Santos, S.P.Y., $\quad$ E. Delbone, E.F. Carvalho and L.N. Martins, 2010. Synchronous generator disturbance provoked by induction motor starting. Am. J. Applied Sci., 7: 962-968. DOI: 10.3844/ajassp.2010.962.968

Zarate-Minano, R., T.V. Custsem, F. Milano and A.J. Conejo, 2010. Securing transient stability using time-domain simulations within an optimal power flow. IEEE Trans. Power Syst., 5: 243-253. DOI: 10.1109/TPWRS.2009.203069 